\title{
Dispersal of Aedes aegypti and Aedes albopictus (Diptera: Culicidae) in an Urban Endemic Dengue Area in the State of Rio de Janeiro, Brazil
}

\author{
Nildimar Alves Honório/+ , Wellington da Costa Silva*, Paulo José Leite*, Jaylei Monteiro \\ Gonçalves**, Leon Philip Lounibos***, Ricardo Lourenço-de-Oliveira
}

\begin{abstract}
Laboratório de Transmissores de Hematozoários, Instituto Oswaldo Cruz-Fiocruz, Av. Brasil 4365, 21045-900 Rio de Janeiro, RJ, Brasil *Fundação Nacional de Saúde-Distrito Sanitário de Nova Iguaçu, Nova Iguaçu, RJ, Brasil **Departamento de Química, Instituto Nacional de Controle e Qualidade e Saúde-Fiocruz, Rio de Janeiro, RJ, Brasil ***Florida Medical Entomology Laboratory, University of Florida, Florida, USA
\end{abstract}

Experimental releases of female Aedes (Stegomyia) aegypti and Aedes (Stegomyia) albopictus were performed in August and September 1999, in an urban area of Nova Iguaçu, State of Rio de Janeiro, Brazil, to estimate their flight range in a circular area of 1,600 $\mathrm{m}$ where 1,472 ovitraps were set. Releases of 3,055 Ae. aegypti and 2,225 Ae. albopictus females, fed with rubidium (Rb)-marked blood and surgically prevented from subsequent blood-feeding, were separated by 11 days. Rb was detected in ovitrap-collected eggs by atomic emission spectrophotometry. Rbmarked eggs of both species were detected up to $800 \mathrm{~m}$ from the release point. Eggs of Ae. albopictus were more numerous and more heterogeneously distributed in the area than those of Ae. aegypti. Eggs positively marked for $R b$ were found at all borders of the study area, suggesting that egg laying also occurred beyond these limits. Results from this study suggest that females can fly at least $800 \mathrm{~m}$ in 6 days and, if infected, potentially spread virus rapidly.

Key words: Aedes aegypti - Aedes albopictus - behavior - dispersal - rubidium - dengue - Rio de Janeiro - Brazil

Female mosquitoes may disperse to find mates, food or oviposition sites. Dispersal to seek a host is epidemiologically important as the mechanism whereby female mosquitoes acquire and disseminate pathogens. Additionally, dispersal for oviposition is relevant to disease propagation. Females of the classic dengue vector Aedes aegypti (Linnaeus) distribute their eggs among several oviposition sites (Christophers 1960, Reiter et al. 1995) and frequently take multiple blood meals within a single gonotrophic cycle (McClelland \& Conway 1971, Trpis \& Hausermann 1986, Scott et al. 1993), which increases dispersal of their progeny. According to Trpis and Hausermann (1986), Ae. aegypti also disperse to search for carbohydrates and a mate.

Studies on the dispersal of Ae. aegypti show females generally fly $100-500 \mathrm{~m}$ (McDonald 1977, Trpis \& Hausermann 1986, Muir \& Kay 1998). This range is short compared to other mosquitoes, such as Aedes taeniorhynchus (Wiedemann) which disperse up to $10 \mathrm{~km}$ (Provost 1957). Some authors believe that Ae. aegypti fly only a short distance from their emergence sites (Reuben et al. 1975, Trpis \& Hausermann 1986, Trpis et al. 1995, Service 1997). However, a study conducted in urban San Juan, Puerto Rico, showed that female Ae. aegypti could,

Research supported by Fiocruz, CNPq (grants 52.1474/95-7), Papes-Fiocruz (grants 0250.250.392) and U.S. National Institutes of Health grant AI-44793 (to LPL).

${ }^{+}$Corresponding author. Fax: +55-21-2573.4468. E-mail: honorio@ioc.fiocruz.br

Received 23 July of 2002

Accepted 25 November 2002 in a few days, travel at least $441 \mathrm{~m}$ from a releasing point (Reiter et al. 1995). Recapture studies of marked female Aedes albopictus (Skuse), another potential dengue vector (Schatzmayr 2000), showed a maximum dispersal of 400-600 m (Rosen et al. 1976, Niebylski \& Craig 1994). This same species flew no more than $200 \mathrm{~m}$ in studies in Hawaii and Japan (Bonnet \& Worcester 1946, Mori 1979).

Despite its importance to dengue transmission, dispersal of Ae. aegypti and Ae. albopictus in urban Brazil has not been examined. In order to assess and compare their pre-oviposition dispersal, we fed adult females on blood enriched with rubidium chloride $(\mathrm{RbCl})$ a method developed by Kimsey and Kimsey (1984). The release of $\mathrm{Rb}$-marked females was carried out in an endemic dengue area of Southeastern Brazil, and dispersal was measured by the detection of Rb-labeled eggs in ovitraps.

\section{MATERIALS AND METHODS}

Study area - Nova Iguaçu is a municipality of the State of Rio de Janeiro, Brazil, located at $22^{\circ} 45^{\prime} \mathrm{S} 43^{\circ} 27^{\prime} \mathrm{W}, 25 \mathrm{~m}$ altitude, with an area of $566.6 \mathrm{~km}^{2}$ (Fig. 1). Atlantic forest is still present in $35 \%$ of this area, although it is predominantly urban. The climate is hot and humid, with annual temperature and rainfall averages of $22^{\circ} \mathrm{C}$ and $2,100 \mathrm{~mm}$, respectively. Nova Iguaçu has an approximately population of 850,000 inhabitants, with an average density of 1,414 inhabitants $/ \mathrm{km}^{2}$ (Prefeitura Municipal de Nova Iguaçu 1999, Honório 1999, Honório \& Lourenço-deOliveira 2001). The release point was chosen as the center of a circle with an $800 \mathrm{~m}$ radius that encompassed seven districts of Nova Iguaçu: Ambaí, Bela Vista, Boa Esperança, Figueira, Jardim Ocidental, Miguel Couto and Parque Flora (Fig. 1). These districts are essentially residential areas with small shops, have a limited sewage system, and sparse 
solid waste refuse collection. Figueira is unique among these in having a rural area, with low population density (Fig. 1).

Entomological inspection - Two weeks before the release of Rb-marked mosquitoes, all houses (nearly 5,000) located in the $1,600 \mathrm{~m}$ diameter study area were inspected for containers containg immature mosquitoes which were identified and counted. Containers yielded 5,280 immatures identified as 3,055 Ae. aegypti and 2,225 Ae. albopictus. Most of the small containers that represented potential breeding sites for Aedes mosquitos were eliminated or removed by collectors, and the others, particularly large ones such as water reservoirs, were treated with Temephos ${ }^{\circledR}(20 \mathrm{~g} / 10001$ of water) to kill the larvae. These procedures were done to avoid increases in mosquito density attributable to oviposition by released females.

Oviposition traps - 1,472 ovitraps were placed in shaded peridomestic areas located at ground level and protected from the rain. In order to distribute the ovitraps homogeneously, the $800 \mathrm{~m}$ radius circular area was divided in to five concentric areas of $0-100 \mathrm{~m}$ radius $(23$ ovitraps), 100-200 m (69 ovitraps), 200-400 m (276), 400$600 \mathrm{~m}$ (460) and 600-800 m (644), respectively (Fig. 1). Each ovitrap contained $270 \mathrm{ml}$ of tap water and $30 \mathrm{ml}$ of a $10 \%$ by weight aqueous hay infusion that had been previously incubated for 7 days. A $12 \mathrm{~cm} \times 5 \mathrm{~cm}$ wooden paddle was placed in each ovitrap. On the third day after setting all paddles were collected and replaced with new ones.

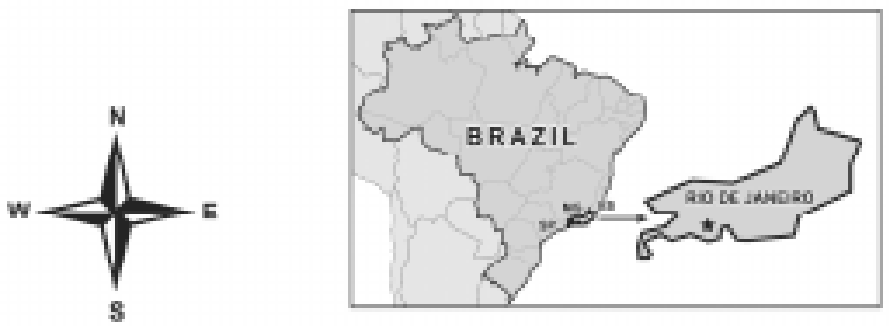

Ovitrap

Release point

- - Railroad

Street

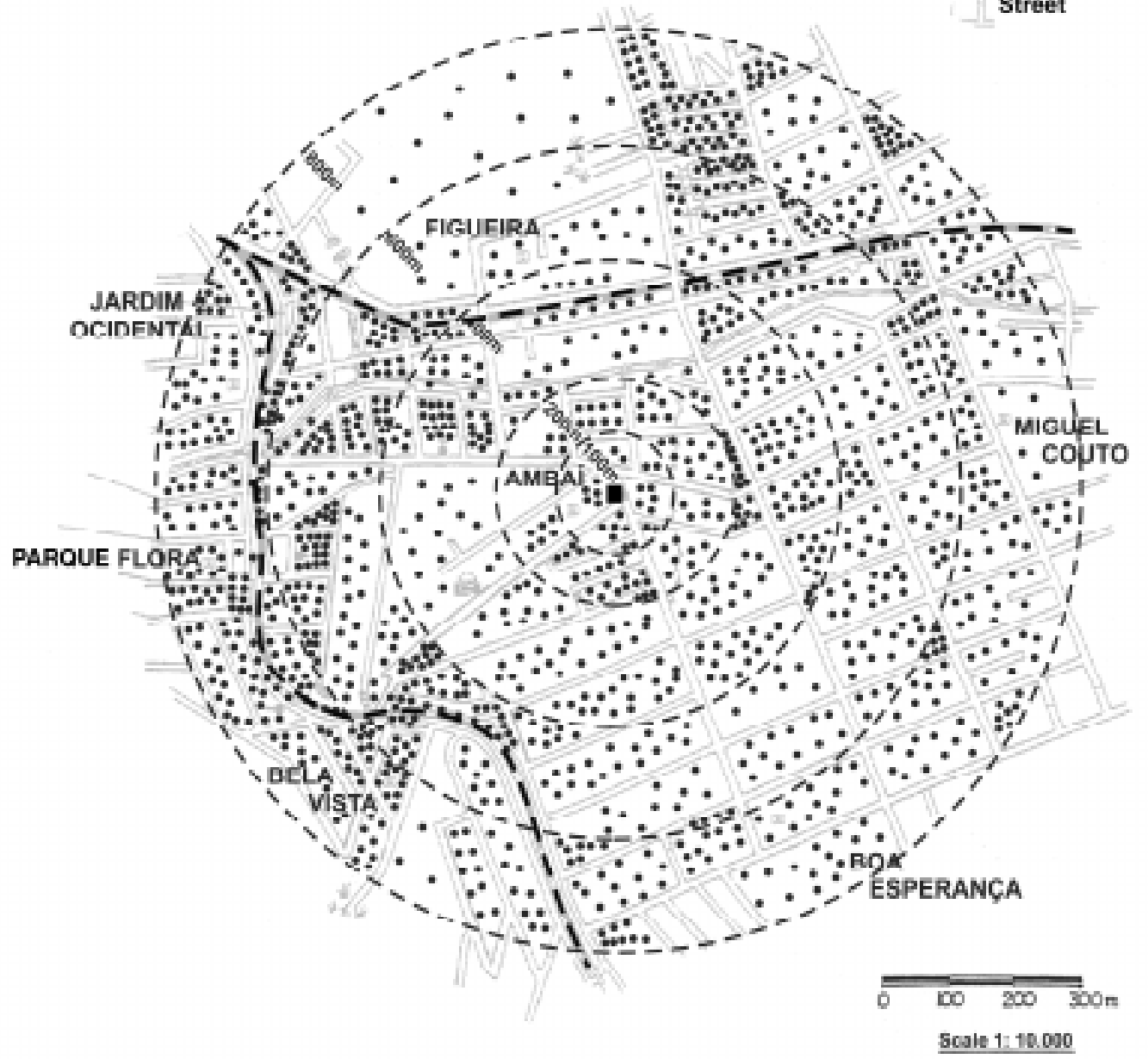

Fig. 1: municipality of Nova Iguaçu, State of Rio de Janeiro, Brazil, where field work was conducted. Each dot represents an ovitrap placed within a circular area of $1,600 \mathrm{~m}$ diameter. 
Throughout the study, missing ovitraps were replaced with new traps.

Mosquitoes - Ae. aegypti and Ae. albopictus mosquitoes used in the experiments were $\mathrm{F}_{3}$ from laboratory colonies derived from large numbers of eggs collected in Ambaí. Mosquito colonies were maintained in an insectary at $27 \pm 1^{\circ} \mathrm{C}$ and $80 \pm 10 \%$ humidity. Larvae were fed with fish food (Tetramin $\left.{ }^{\circledR}\right)$ and reared according to Consoli and Lourenço-de-Oliveira (1994). Adults of both species were provided with sucrose solution from emergence to one day before blood feeding.

Blood meal mixed with $\mathrm{RbCl}$ - Four to six day old $\mathrm{F}_{3}$ females were separated from males in cardboard cylindrical cages ( $9 \mathrm{~cm}$ height, $9 \mathrm{~cm}$ diameter). These females were offered defibrinated sheep blood containing $0.025 \mathrm{M} \mathrm{RbCl}$ (Reiter et al. 1995). Rb is an alkali metal, non-toxic to plants, insects and other animals, that is incorporated into ovarian follicles and accumulates in mosquito eggs if it is present in the blood meal (Kimsey \& Kimsey 1984, Anderson et al. 1990). Eggs containing Rb were detected by atomic emission spectrophotometry (Reiter et al. 1995). A $\mathrm{Rb}$-marked blood meal was offered to mosquito females in a feeding apparatus described by Rutledge (1964). Females that fed to repletion were kept in cages $(60 \times 60 \times 60$ $\mathrm{cm}$ ) in the insectary. Twenty-four hours after the Rb-blood meal, the tip of proboscises of all Ae. aegypti and Ae. albopictus females were cut off with a dissection scissors to prevent subsequent feeding. This procedure prior to release was recommended by the institutional ethics committee to avoid the risk of increased virus transmission in the dengue endemic area. Available evidence suggests that proboscis amputation should not affect postfeeding dispersal for oviposition (Shirai et al. 2000).

In order to assess both timing of oviposition and effectiveness of $\mathrm{Rb}$ detection, 12 females of each species received an $\mathrm{Rb}$-blood meal and were housed in the laboratory in individual glass cylinders $(7 \times 2.5 \mathrm{~cm})$ containing filter paper and dechlorinated water at the bottom. Eggs were recovered up to five days after blood feeding and tested for the presence of $\mathrm{Rb}$ as described below. $\mathrm{Rb}$ was detected in 9/12 (75\%) Ae. aegypti and 11/12 (91\%) Ae. albopictus. These frequencies were not significantly different from one another $(P=0.771$, Fisher exact test $)$.

Release of Rb-marked females - One day after a Rbblood meal, gravid females were released at dusk (1700$1900 \mathrm{~h}$ ) at the center of the study area (Fig. 1). Two Rb female releases were performed, one for each species. A total of 3,055 Ae. aegypti and 2,225 Ae. albopictus females were released on August 17 and 28, 1999, respectively. The 11 day interval between releases was considered sufficient to distinguish between the species because the chances of Ae. aegypti laying eggs more than 13 days after a single blood meal, and deprived of additional blood meals, is very small (Christophers 1960).

Ovitrap collections and Rb-marked eggs detection On the third day after releases, the wooden paddles in each ovitrap were collected and replaced by fresh paddles. The replacement paddles were subsequently collected after an additional three days. The number of eggs collected per paddle was estimated after examination with a stereomicroscope. All eggs from a positive paddle were gently transferred to a $10 \mathrm{ml}$ glass flask to which $2 \mathrm{ml}$ of nitric acid were added. The flasks were heated to $100^{\circ} \mathrm{C}$ on a hot plate for $30 \mathrm{~min}$, followed by the addition of $1 \mathrm{ml}$ distilled water. Each sample was analyzed by atomic emission spectrophotometry (Perkin Elmer model 5500). Eggs from laboratory colonies of Ae. aegypti and Ae. albopictus were used as controls for each assay.

Statistical analysis - Data were analyzed by chi-square and Fisher exact tests using SPSS for Windows (8.0). Chisquare tests were used to compare frequencies of $\mathrm{Rb}$ positive ovitraps in different portions of the study area.

\section{RESULTS}

Egg trap collection for Rb detection - Of the 1,472 ovitraps placed in the study area, 1,347 were recovered on the third day after the release of Rb-marked Ae. aegypti females. On the sixth day 1,411 out of 1,472 ovitraps were recovered. The remaining 186 paddles $(6.3 \%)$ were missing. For Ae. albopictus, on the third day after release, 1,433 of 1,472 ovitraps were recovered and on the sixth day, 1,381 of 1,472 ovitraps. In total, 120 paddles $(4.1 \%)$ were missing. For both species, more Rb-eggs were detected on the sixth day (Tables I, II).

Dispersal of Ae. aegypti - Fifty-one ovitraps (17 on day 3 and 34 on day 6) were found with Rb-marked Ae. aegypti eggs (Table I, Fig. 2). Ambaí and Jardim Ocidental were the districts with the highest number of Rb-positive eggs (28 positive ovitraps out of 1,400 set), followed by Miguel Couto (8), Figueira (6), Boa Esperança (5) and Bela Vista and Parque Flora (4). Ae. aegypti Rb-marked eggs were found up to $800 \mathrm{~m}$ from the release point. None of the 23 ovitraps placed up to $100 \mathrm{~m}$ from the release point was positive for $\mathrm{Rb}$ - marked Ae. aegypti eggs. In the 100$200 \mathrm{~m}$ area, where 118 paddles were recovered, only 2 $(1.7 \%)$ were positive (Table III). In the $200-400 \mathrm{~m}$ area, 12 had Rb-marked Ae. aegypti eggs (or $2.3 \%$ of the 515 recovered). Out of the 850 paddles collected in the 400-600 $\mathrm{m}, 20(2.3 \%)$ were positive while in the $600-800 \mathrm{~m}$ area there were $17(1.3 \%)$. The percentages of positive paddles were not significantly different among areas divided either as concentric circles $\left(\chi^{2}=3.3, \mathrm{df}=4, P=0.503\right.$; Table III), pie-shaped wedges of equivalent size $\left(\chi^{2}=4.76, \mathrm{df}=\right.$ $7, P=0.688$; Table IV $)$ or by districts $\left(\chi^{2}=2.37, \mathrm{df}=4, P>\right.$ 0.05 ; Table I).

Dispersal of Ae. albopictus - A total of 304 ovitraps were recovered with Rb-marked Ae. albopictus eggs: 95 on day 3 and 209 on day 6 after release of Rb-marked females (Table II, Fig. 2). As for Ae. aegypti, Ambaí and Jardim Ocidental were the districts with the most Rbmarked eggs (127 positive ovitraps), followed by Miguel Couto (79), Figueira (47), Bela Vista and Parque Flora (28) and Boa Esperança (23). Ae. albopictus Rb-marked eggs were also found up to $800 \mathrm{~m}$ from the release point. A total of 8 ovitraps placed up to $100 \mathrm{~m}$ from the release point were positive for Rb-marked eggs (18.2\%). In the 100-200 $\mathrm{m}$ area, where 127 paddles were recovered, 21 (16.5\%) were positive. In the $200-400 \mathrm{~m}$ area, 50 had $\mathrm{Rb}$-marked eggs $(9.5 \%$ of the 525$)$. Out of the 875 paddles collected in the $400-600 \mathrm{~m}$ area, $82(9.3 \%)$ were positive and in the 600 $800 \mathrm{~m}$ area there were $143(11.4 \%)$ positive. Ae. albopictus $\mathrm{Rb}$ positive eggs were found in all blocks in the experi- 
mental area, even in those located as far as $800 \mathrm{~m}$ for the release point. The percentages of positive paddles were significantly different among areas divided either as concentric circles $\left(\chi^{2}=10.08, \mathrm{df}=4, P=0.039\right.$; Table III), pieshaped wedges of equivalent size $\left(\chi^{2}=32.24, \mathrm{df}=7, P<\right.$ $0.001)$ or by districts $\left(\chi^{2}=10.43, \mathrm{df}=4, P=0.034\right.$; Table II).

\section{DISCUSSION}

In the preliminary laboratory experiment in which females were kept individually in glass vials, $75 \%$ of $A e$. aegypti and $91 \%$ of Ae. albopictus females laid Rb-marked eggs. Although this difference between species was not statistically significant, the trend corresponds to the

TABLE I

Number of wooden paddles set and recovered with or without eggs and numbers of paddles with rubidium (Rb)-marked eggs, in districts of the study area in Nova Iguaçu, State of Rio de Janeiro, Brazil, after the release of 3,055 Rb-marked blood fed Aedes aegypti females on August 17, 1999. Egg collections performed on August 20 (first collection) and 23 (second collection)

\begin{tabular}{|c|c|c|c|c|c|c|c|}
\hline \multirow[b]{2}{*}{ District } & \multirow[b]{2}{*}{ Set } & \multicolumn{2}{|c|}{$\begin{array}{l}\text { Without eggs } \\
\text { collection }\end{array}$} & \multicolumn{2}{|c|}{$\begin{array}{l}\text { With eggs } \\
\text { collection }\end{array}$} & \multicolumn{2}{|c|}{$\begin{array}{l}\text { With Rb-marked } \\
\text { eggs collection }\end{array}$} \\
\hline & & $1 \mathrm{st}$ & 2nd & $1 \mathrm{st}$ & 2nd & $1 \mathrm{st}$ & 2nd \\
\hline Ambaí and Jardim Ocidental & 700 & 651 & 665 & 22 & 51 & 7 & 21 \\
\hline Bela Vista and Parque Flora & 198 & 164 & 183 & 4 & 10 & 2 & 2 \\
\hline Boa Esperança & 117 & 106 & 96 & 6 & 19 & 1 & 4 \\
\hline Figueira & 221 & 196 & 188 & 8 & 17 & 2 & 4 \\
\hline Miguel Couto & 236 & 175 & 165 & 15 & 17 & 5 & 3 \\
\hline \multirow[t]{2}{*}{ Total } & 1,472 & 1,292 & 1,297 & 55 & 114 & 17 & 34 \\
\hline & $2_{(4)}=2.37$ & & & \multicolumn{4}{|c|}{$P>0.05$} \\
\hline
\end{tabular}

$\chi^{2}$ : test for significant frequency differences of $\mathrm{Rb}$-positive paddles among districts

TABLE II

Numbers of wooden paddles set and recovered with or without eggs and numbers of paddles with rubidium (Rb)-marked eggs, in districts the study area in Nova Iguaçu, State of Rio de Janeiro, Brazil, after the release of 2,225 Rb-marked blood fed Aedes albopictus females on August 28, 1999. Egg collections performed on August 31 (first collection) and September 3 (second collection)

\begin{tabular}{|c|c|c|c|c|c|c|c|}
\hline \multirow[b]{2}{*}{ District } & \multirow[b]{2}{*}{ Set } & \multicolumn{2}{|c|}{$\begin{array}{c}\text { Without eggs } \\
\text { collection }\end{array}$} & \multicolumn{2}{|c|}{$\begin{array}{l}\text { With eggs } \\
\text { collection }\end{array}$} & \multicolumn{2}{|c|}{$\begin{array}{l}\text { With Rb-marked } \\
\text { eggs collection }\end{array}$} \\
\hline & & $1 \mathrm{st}$ & 2nd & $1 \mathrm{st}$ & 2nd & $1 \mathrm{st}$ & 2nd \\
\hline Ambaí and Jardim Ocidental & 700 & 580 & 408 & 185 & 261 & 45 & 82 \\
\hline Bela Vista and Parque Flora & 198 & 151 & 149 & 37 & 45 & 11 & 17 \\
\hline Boa Esperança & 117 & 77 & 81 & 32 & 32 & 10 & 13 \\
\hline Figueira & 221 & 112 & 131 & 59 & 79 & 17 & 30 \\
\hline Miguel Couto & 236 & 123 & 85 & 87 & 110 & 12 & 67 \\
\hline \multirow[t]{2}{*}{ Total } & 1,472 & 1,043 & 854 & 400 & 527 & 95 & 209 \\
\hline & \multicolumn{3}{|c|}{$\chi_{(4)}^{2}=10.43$} & \multicolumn{4}{|c|}{$P<0.05$} \\
\hline
\end{tabular}

$\chi^{2}$ : test for significant frequency differences of $\mathrm{Rb}$-positive paddles among districts

TABLE III

Dispersal distances of Aedes aegypti and Aedes albopictus females in Nova Iguaçu, State of Rio de Janeiro, Brazil, August and September 1999

\begin{tabular}{cccccc}
\hline & \multicolumn{2}{c}{ Aedes aegypti } & & \multicolumn{2}{c}{ Aedes albopictus } \\
\cline { 2 - 3 } Distance $(\mathrm{m})$ & $\begin{array}{c}\text { Number of } \\
\text { paddles recovered }\end{array}$ & $\begin{array}{c}\text { Number of rubidium (Rb)- } \\
\text { positive paddles }(\%)\end{array}$ & & $\begin{array}{c}\text { Number of } \\
\text { paddles recovered }\end{array}$ & $\begin{array}{c}\text { Number of } \\
\text { Rb-positive paddles }(\%)\end{array}$ \\
\hline $0-100 \mathrm{~m}$ & 43 & $0 / 0$ & 44 & $8 / 18.2$ \\
$100-200 \mathrm{~m}$ & 118 & $2 / 1.7$ & 127 & $21 / 16.5$ \\
$200-400 \mathrm{~m}$ & 515 & $12 / 2.3$ & 525 & $50 / 9.5$ \\
$400-600 \mathrm{~m}$ & 850 & $20 / 2.3$ & 875 & $82 / 9.3$ \\
$600-800 \mathrm{~m}$ & 1,232 & $17 / 1.3$ & 1,253 & $143 / 11.4$ \\
\hline$\chi_{(4)}^{2}=3.33$ & $P>0.05$ & $\chi_{(4)}^{2}=10.08$ & $P<0.05$ \\
\hline
\end{tabular}

$\chi^{2}$ : test for significant frequency differences among concentric rings 

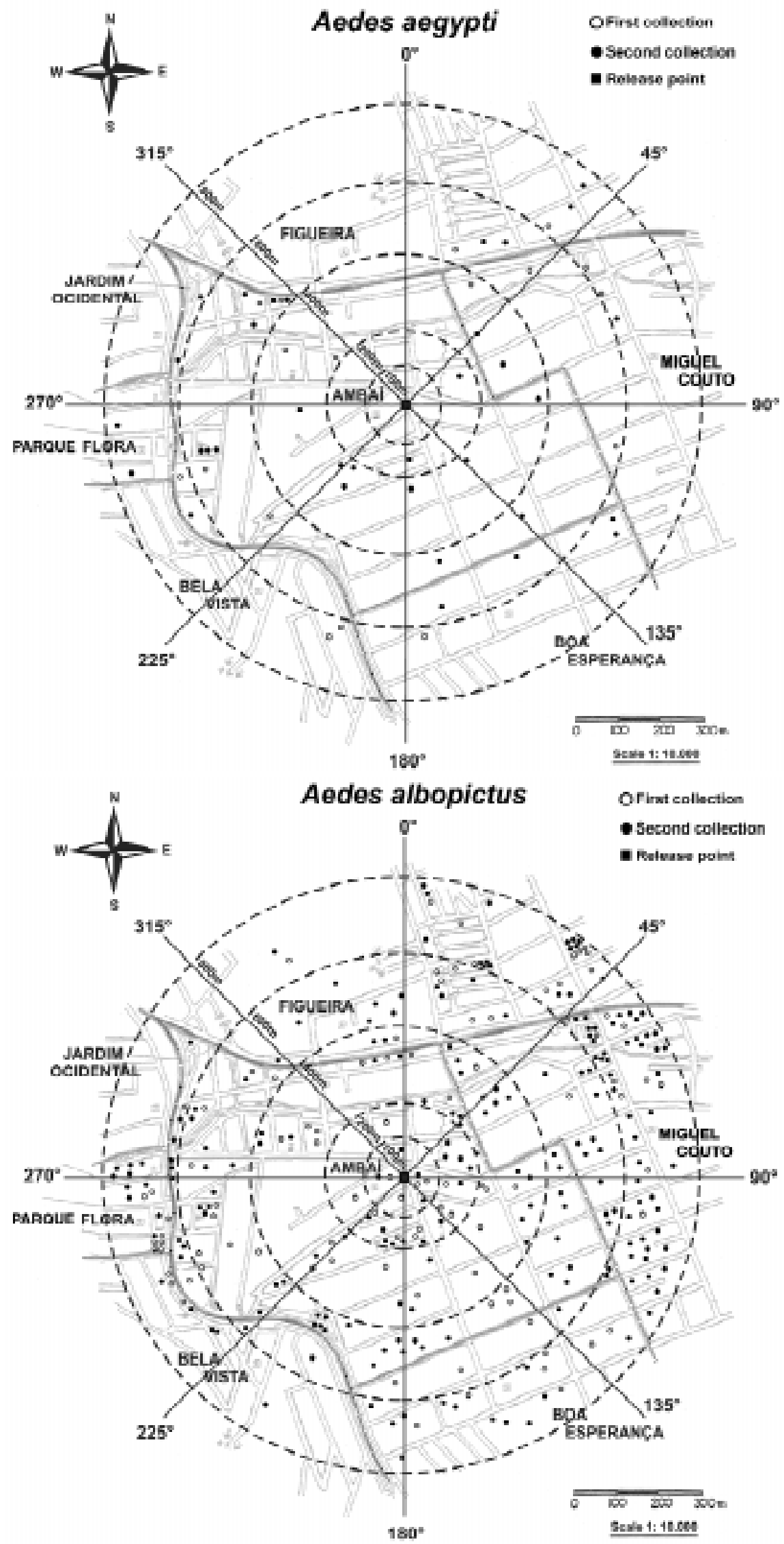

Fig. 2: distribution of collections of rubidium-marked eggs of Aedes aegypti and Aedes albopictus in a circular area of 1,600 m diameter in the municipality of Nova Iguaçu, State of Rio de Janeiro, Brazil, according to districts, and dispersal distances and directions. 
poorer recovery of Rb-positive Ae. aegypti in the field experiment. Although more Ae. aegypti females were released in the field than Ae. albopictus, more Rb-positive paddles of the latter were collected.

The flight of mosquitoes is influenced by factors such as species-specific traits, oviposition site availability, climate (e.g., wind, humidity, temperature, rainfall), terrain, vegetation, housing characteristics (for synanthropic species) and blood source (Forattini 1962). Our experiment changed the number and location of available oviposition sites in the study area, and we cannot discount the possibility that these alterations influenced the dispersal patterns of the released mosquitoes.

$\mathrm{Rb}$-marked Ae. aegypti eggs were found as far as 800 $\mathrm{m}$ from the release point (Table I, Fig. 2). These results indicate a greater flight range for Ae. aegypti than those estimated by other authors who suggest $\leq 200 \mathrm{~m}$ (Morlan \& Hayes 1958, Sheppard et al. 1969, Reuben et al. 1975, Trpis \& Hausermann 1986).

In Brazil, female Ae. aegypti were released inside a house in an urban area of the State of Bahia and the maximum recovery distance after $24 \mathrm{~h}$ was $120 \mathrm{~m}$ (Shannon et al. 1930). In a second experiment, the maximum dispersal distance was $300 \mathrm{~m}$ for two individuals (Shannon \& Davis 1930). Because of the difficulties in recapture of Ae. aegypti, owing to its escape ability and behavior when approaching for blood (Christophers 1960), both values should be considered underestimates of the true flight range of the species. In a third experiment, 12,000 females were marked with methylene blue and released in a boat anchored in the sea $1 \mathrm{~km}$ from the coast (Shannon \& Davis 1930). Only eight specimens were recovered on land, indicating that, dispersal of up to $1 \mathrm{~km}$ is possible for Ae. aegypti. Conditions were also unnatural for gravid Ae. aegypti females released in the desert of Israel (Wolfinshon \& Galun 1953), a zone free of Ae. aegypti with no houses that could act as adult attractants. Under these conditions, oviposition of Ae. aegypti was recorded as far as 2,500 $\mathrm{m}$ from the release point.

In our field study, paddles were collected on days 3 and 6 after release, that correspond to 4 and 7 days after the blood meal, respectively. Paddles with $\mathrm{Rb}$-positive eggs were more numerous on day 6. Because Ae. aegypti generally lays eggs 3 to 5 days after a blood meal (Christophers 1960), some females may not have been ready to oviposit before the first paddle-collection.

The number of ovitraps with Rb-positive eggs was highest for Ae. aegypti at Ambaí and Jardim Ocidental (Table I), but the number of ovitraps set there was also greater, as these districts encompass most of the study area (Fig. 1). Positive ovitraps were also common along the railroad that crosses Parque Flora and Figueira, which are mostly poor neighborhoods of rudimentary housing in an undulating terrain. In these districts the water supply is irregular, which leads inhabitants to store water in containers. It is likely that these containers are used as oviposition sites by container dwelling mosquitoes.

The recovery of marked Ae. aegypti eggs was not significantly different among 5 concentric circles up to $800 \mathrm{~m}$ from the release point. The overall low recovery of $\mathrm{Rb}$ positive paddles for Ae. aegypti contributed to the ab- sence of detectable differences in dispersal of this species among districts or sectors of the study area.

Studies on Ae. albopictus dispersal have not been previously done in Brazil. In Missouri, USA, non-blood fed Ae. albopictus females marked with fluorescent dyes dispersed up to $525 \mathrm{~m}$ (female) and $225 \mathrm{~m}$ (male) (Niebylski $\&$ Craig 1994). We observed a dispersal range of at least $800 \mathrm{~m}$ for this species. In the $600-800 \mathrm{~m}$ area 143 ovitraps were positive for $\mathrm{Rb}$-marked eggs, (11.4\% of 1,253 paddles).

Egg distribution in the study area was significantly heterogeneous for Ae. albopictus but not for Ae. aegypti (Tables III, IV, Fig. 2). When Ae. albopictus were released, winds were blowing to the east, which could have contributed to biased dispersal. Although the number of $A e$. albopictus released females $(2,225)$ was lower than that of Ae. aegypti $(3,055)$, more marked Ae. albopictus eggs were recovered in ovitraps (Table II). The highest frequency of Rb-marked eggs occurred in the 100-200 m area (Fig. 2). Frequencies of Rb-marked eggs of Ae. albopictus were significantly different among the districts, among concentric circles, and among pie-shaped wedges of equivalent size. 'Hot spots' of recovery were concentrated in Figueira and Miguel Couto, mainly at the $600-800 \mathrm{~m}$ area. The recovery of Rb-positive ovitraps was significantly higher in sectors 1 and 2 than in sectors 7 and 8 (Table IV). Unlike sectors 7 and 8, the terrain of sectors 1 and 2 is hillier, the houses have trees in the yards, and are separated by patches of pasture. This result agrees with known preferences of this species for rural and vegetated habitats (Hawley 1988).

The dispersal of Ae. aegypti and Ae. albopictus at least $800 \mathrm{~m}$ occurred in a dengue endemic area within a 6 day period. It is known that the extrinsic incubation period of dengue virus, the interval of time from acquisition of infectious blood to subsequent transmission, is approximately 11-14 days for Ae. aegypti (Siler et al. 1926). If a female feeding once on a viremic inhabitant can fly at least $800 \mathrm{~m}$ in 6 days, it can spread the virus very rapidly. This extensive flight range must be taken into account in focal insecticidal treatment in response to yellow fever or dengue outbreaks. A new dengue case could appear at 1 $\mathrm{km}$ distance from another in few days. This has been observed in previous dengue epidemics, when time for control action measures was minimal between the first confirmed cases and the rapid spread of the disease (Kuno 1995). Rapid dispersal would also apply to Aedes re-infestation of areas considered free of these vectors. Our results suggests that from an initial focus, in 6 days one might expect house infestation of almost $1 \mathrm{~km}^{2}$ due to female dispersal independent of human activies, such as transport and trade. It is clear that female dispersal by flight has the potential to be very important for the spread of dengue vectors, either between adjacent cities or in urban centers such as Rio de Janeiro.

\section{ACKNOWLEDGEMENTS}

To Dr Pedro Cabello for guidance on statistical procedures, Drs MG Rosa-Freitas, D Valle, François Noireau, BW Alto, and SP Yanoviak for comments and critical review of the manuscript. To Dr Silvana Jacobs for her valuable advice. To Genilton 
TABLE IV

Dispersal directions of Aedes aegypti and Aedes albopictus females in Nova Iguaçu, State of Rio de Janeiro, Brazil, August and September 1999

\begin{tabular}{|c|c|c|c|c|c|}
\hline \multirow[b]{2}{*}{ Distance (m) } & \multirow[b]{2}{*}{$\operatorname{Arc}\left(45^{\circ}\right)$} & \multicolumn{2}{|c|}{ Aedes aegypti } & \multicolumn{2}{|c|}{ Aedes albopictus } \\
\hline & & $\begin{array}{c}\text { Number of } \\
\text { paddles recovered }\end{array}$ & $\begin{array}{c}\text { Number of rubidium }(\mathrm{Rb})- \\
\text { positive paddles }(\%)\end{array}$ & $\begin{array}{l}\text { Number of } \\
\text { paddles recovered }\end{array}$ & $\begin{array}{c}\text { Number of } \\
\text { Rb-positive paddles }(\%)\end{array}$ \\
\hline 3 & $0-45^{\circ}$ & 388 & $8 / 2.1$ & 391 & $45 / 11.5$ \\
\hline 1 & $45-90^{\circ}$ & 374 & $7 / 1.9$ & 374 & $63 / 16.8$ \\
\hline 2 & $90-135^{\circ}$ & 316 & $5 / 1.6$ & 328 & $47 / 14.3$ \\
\hline 4 & $135-180^{\circ}$ & 287 & $6 / 2.1$ & 309 & $33 / 10.7$ \\
\hline 7 & $180-225^{\circ}$ & 311 & $4 / 1.3$ & 319 & $26 / 8.1$ \\
\hline 6 & $225-270^{\circ}$ & 473 & $11 / 2.3$ & 489 & $45 / 9.2$ \\
\hline 8 & $270-315^{\circ}$ & 451 & $10 / 2.2$ & 451 & $28 / 6.2$ \\
\hline 5 & $315-360^{\circ}$ & 158 & $0 / 0$ & 163 & $17 / 10.42$ \\
\hline & & $\chi_{(7)}^{2}=4.76^{a}$ & $P>0.05$ & $\chi_{(7)}^{2}=32.24$ & $P<0.001$ \\
\hline
\end{tabular}

a: unplanned test for homogeneity (Sokal \& Rohlf 1981). For Ae. albopictus, sectors sharing common line are statistically homogeneous: 12345678

Vieira and James M Newman who assisted the authors with the figures, and to the technicians of Fundação Nacional de Saúde for logistical support in the field.

\section{REFERENCES}

Anderson RA, Edman JD, Scott TW 1990. Rubidium and cesium as host blood-markers to study multiple blood feeding by mosquitoes (Diptera: Culicidae). J Med Entomol 27: 999-1001.

Bonnet DD, Worcester DJ 1946. The dispersal of Aedes albopictus in the territory of Hawaii. Am J Trop Med 26: 465-476.

Christophers SR 1960. Aedes aegypti (L.). The Yellow Fever Mosquito, Cambridge University Press, London, 739 pp.

Consoli RAGB, Lourenço-de-Oliveira R 1994. Principais Mosquitos de Importância Sanitária no Brasil, Fiocruz, Rio de Janeiro, $225 \mathrm{pp}$.

Forattini OP 1962. Entomologia Médica, Vol. I, Univ. São Paulo, São Paulo, 662 pp.

Hawley WA 1988. The biology of Aedes albopictus. J Am Mosq Control Assoc 4 (Suppl. 1): 1-40.

Honório NA 1999. Estudo de Aspectos da Biologia do Aedes aegypti (Linnaeus, 1762) e Aedes albopictus (Skuse, 1894), em Area Endêmica de Dengue, no Estado do Rio de Janeiro, MSc Thesis, Instituto Oswaldo Cruz-Fiocruz, Rio de Janeiro, 83 pp.

Honório NA, Lourenço-de-Oliveira R 2001. Freqüência de larvas e pupas de Aedes aegypti e Aedes albopictus em armadilhas, Brasil. Rev Saúde Púb 34: 385-391.

Kimsey RB, Kimsey PB 1984. Identification of arthropod blood meals using rubidium as a marker: a preliminary study. J Med Entomol 21: 714-719.

Kuno G 1995. Review of the factors modulating dengue transmission. Epidemiol Rev 17: 321-335.

McClelland GAH, Conway GR 1971. Frequency of blood feeding in the mosquito Aedes aegypti. Nature 232: 485-486.

McDonald PT 1977. Population characteristics of domestic Aedes aegypti (Diptera: Culicidae) in villages on the Kenya coast. II. Dispersal within and between villages. J Med Entomol 14: 49-53.

Mori A 1979. Effects of larval density and nutrition on some attributes of immature and adult Aedes albopictus. Trop Med 21: 85-103.
Morlan HB, Hayes RO 1958. Urban dispersal and activity of Aedes aegypti. Mosq News 18: 137-144.

Muir LE, Kay BH 1998. Aedes aegypti survival and dispersal estimated by mark-release-recapture in Northern Australia. Am J Trop Med Hyg 58: 277-282.

Niebylski ML, Craig JrGB 1994. Dispersal and survival of Aedes albopictus at a scrap tire yard in Missouri. J Am Mosq Control Assoc 10: 339-343.

Prefeitura Municipal de Nova Iguaçu 1999. 1000 dias de Governo Nelson Bornier. Dados disponibilizados na Internet: http// www. pmni.com.br

Provost MW 1957. The dispersal of Aedes taeniorhynchus. IIThe second experiment. Mosq News 17: 233-247.

Reiter P, Amador MA, Anderson RA, Clark GG 1995. Short report: dispersal of Aedes aegypti in a urban area after blood feeding as demonstrated by rubidium-marked eggs. Am J Trop Med Hyg 52: 177-179.

Reuben R, Rahman SJ, Panicker KN, Das PK, Brooks GD 1975. The development of a strategy for large-scale releases of sterile males of Aedes aegypti (L). J Commun Dis 7: 313326.

Rosen L, Rozeboon LLE, Reeves WC, Saugrain J, Gubler DJ 1976. A field trial of competitive displacement of Aedes polynesiensis by Aedes albopictus on a Pacific atoll. Am J Trop Med Hyg 25: 906-913.

Rutledge LC, Ward RA, Gould DJ 1964. Studies on the feeding response of mosquitoes to nutritive solutions in a new membrane feeder. Mosq News 24: 407-419.

Schatzmayr HG 2000. Dengue situation in Brazil by year 2000. Mem Inst Oswaldo Cruz 95: 179-181.

Scott TW, Clark GG, Lorenz LH, Amerasinghe PH, Reiter P, Edman JD 1993. Detection of multiple blood feeding in Aedes aegypti (Diptera: Culicidae) during a single gonotrophic cycle using a histologic technique. J Med Entomol 30: 9499.

Service MW 1997. Mosquito (Diptera: Culicidae) Dispersal The long and short of it. J Med Entomol 34: 579-588.

Shannon RC, Davis NC 1930. The flight of Stegomyia aegypti. Am J Trop Med Hyg 10: 151-156.

Shannon RC, Burke AW, Davis NC 1930. Observations on released Stegomyia aegypti with special reference to dispersion. Am J Trop Med 10: 145-150.

Sheppard PM, MacDonald WW, Tonn RJ, Grab B 1969. The 
dynamics of an adult population of Aedes aegypti in relation to dengue haemorrhagic fever in Bangkok. J Anim Ecol 38: 661-702.

Shirai Y, Kamimura K, Seki T, Morohashi M 2000. Proboscis amputation facilitates the study of mosquito (Diptera: $\mathrm{Cu}$ licidae) attractants, repellents, and host preference. $J$ Med Entomol 37: 637-639.

Siler JF, Hall MW, Hitchens AP 1926. Dengue: its history, epidemiology, mechanism of transmission, etiology, clinical manifestations, immunity, and prevention. Philipp J Sci 29: 1-304.

Sokal RR, Rohlf FJ 1981. Biometry. The Principles and Practice of Statistics in Biological Research, 2nd ed., Freeman, San
Francisco, $859 \mathrm{pp}$.

Trpis M, Hausermann W 1986. Dispersal and other population parameters of Aedes aegypti in an African village and their possible significance in epidemiology of vector-borne disease. Am J Trop Med Hyg 35: 1263-1279.

Trpis M, Hausermann W, Craig JrGB 1995. Estimates of population size, dispersal, and longevity of domestic Aedes aegypti (Diptera: Culicidae) by mark-release-recapture in the Village of Shauri Moyo in Eastern Kenya. J Med Entomol 32: 27-33.

Wolfinsohn M, Galun R 1953. A method for determining the flight range of Aedes aegypti (Linn). Bull Res Council Israel 2: $433-436$ 